\title{
Reproductive cycle of the salmon-bellied racer, Mastigodryas melanolomus (Serpentes, Colubridae), from Costa Rica
}

\author{
Stephen R. Goldberg \\ Department of Biology, Whittier College, Whittier, California 90608, USA. E-mail: sgoldberg@whittier.edu.
}

Keywords: Serpentes, Colubridae, Mastigodryas melanolomus, reproduction, Costa Rica.

The salmon-bellied racer, Mastigodryas melanolomus (Colubridae, Colubrinae), is known on the Atlantic versant from Tamaulipas, Mexico, to western Panama and on the Pacific slope from Nayarit, Mexico to western Guatemala (Savage 2002). In Costa Rica it is widely distributed in tropical and subtropical rainforest on both versants and in the Valle Central from sea level to $1,700 \mathrm{~m}$ (Solórzano 2004). This diurnal species is both terrestrial and arboreal (Solórzano 2004). It feeds mainly on lizards but also may eat frogs, snakes, reptile eggs and mammals (Seib 1984). Censky and McCoy (1988) reported on the female cycle of M. melanolomus (= Dryadophis melanolomus) from Yucatan, Mexico. Solórzano (2004) reported $M$. melanolomus clutch sizes and monthly occurrences of neonates from Costa Rica. The purpose of this paper is to present new information on the reproductive cycle of $M$. melanolomus from Costa Rica based on histological examination of gonadal material from museum specimens. The first information on the timing of the testicular cycle is also presented.

Received 3 August 2006.

Accepted 23 November 2006.

Distributed December 2006.
A sample of 69 specimens of $M$. melanolomus from Costa Rica (collected 19591983) were examined from the herpetology collection of the Natural History Museum of Los Angeles County (LACM), Los Angeles, California, USA (Appendix I). Counts were made of enlarged ovarian follicles $(>8 \mathrm{~mm}$ length) or oviductal eggs. The left testis, and vas deferens were removed from males and the left ovary was removed from females for histological examination. Tissues were embedded in paraffin, sectioned at $5 \mu \mathrm{m}$ and stained with hematoxylin followed by eosin counterstain. Testes slides were examined to determine the stage of the testicular cycle and ovary slides were examined for the presence of yolk deposition (secondary vitellogenesis sensu Aldridge 1979). Follicles in advanced stages of yolk deposition or oviductal eggs were not examined histologically. Linear regression analysis was used to examine the relationship between female body size and clutch size using Instat (vers. 3.0b, Graphpad Software, San Diego, CA).

Twenty-nine females (mean snout-vent length $[\mathrm{SVL}]=727 \mathrm{~mm} \pm 66 \mathrm{SD}$, range: 621$904 \mathrm{~mm}) ; 26$ males $(\mathrm{SVL}=681 \mathrm{~mm} \pm 144 \mathrm{SD}$, range: $422-941 \mathrm{~mm}$ ) and 14 neonates, $\mathrm{SVL}=$ $254 \mathrm{~mm} \pm 19$ SD, range: $233-297 \mathrm{~mm}$ ) from Costa Rica were examined. 
All testes examined exhibited spermiogenesis with metamorphosing spermatids and sperm present. Vasa deferentia also contained sperm. The following monthly numbers of $M$. melanolomus males were undergoing spermiogenesis: January (1), February (1), March (6), April (1), May (1), June (2), July (4), August (3), September (4), October (2), December (1). The smallest spermiogenic male measured $422 \mathrm{~mm}$ SVL (LACM 153523).

Females with enlarged follicles $(>8 \mathrm{~mm}$ length) or oviductal eggs were observed in January and from March to November (Table 1). Most females reproduced as (86.2\%) were reproductively active (Table 1 ). The smallest reproductively active $M$. melanolomus female (four enlarged follicles) measured $623 \mathrm{~mm}$ SVL (LACM 153429) (Table 2). Mean clutch size was $5.1 \pm 1.1 \mathrm{SD}$, range 2-6. Linear regression analysis for 23 gravid females revealed that the relation between body size (SVL) and clutch size was not significant ( $r=0.19, P=0.39$ ). Individual clutch sizes are given in Table 2. There was no evidence that $M$. melanonomus from Costa Rica produce more than one clutch of eggs per year (oviductal eggs and yolk deposition in the same female) although the existence of reproductively active females during ten months of the year suggests this might be possible.

Neonates of $M$. melanolomus were collected in January ( $n=1)$, March (3), May (1), June (1), July (1), August (1), September (1), October (1), November (2). For two neonates the collection date was given simply as "summer". Solórzano (2004) reported neonates of $M$. melanonomus from August to February.

Results obtained in the present study indicate that M. melanolomus males produce sperm thoughout the year. This characteristic has also been reported in other snakes from Costa Rica: Drymobius margaritiferus (Goldberg 2003a), Dendrophidion sp. (Goldberg 2003b), Ninia maculata (Goldberg 2004a), Erythrolamprus bizona and E. mimus (Goldberg 2004b), and Micrurus nigrocinctus (Goldberg 2004c). Whether this is typical of snakes from this area must await histological examination of testes from additional species of Costa Rican snakes.

Solórzano (2004) previously reported clutches of up to nine eggs in May, June, August and September from M. melanolomus from Costa Rica but gave no minimum or mean clutch size. Thus, I cannot compare my mean clutch

Table 1 - Monthly distribution of stages in the ovarian cycle of 29 Mastigodryas melanolomus from Costa Rica. Values shown (as percentages) are the numbers of females exhibiting each of the four conditions.

\begin{tabular}{lccccc}
\hline Month & $\boldsymbol{n}$ & $\begin{array}{c}\text { No yolk } \\
\text { deposition }\end{array}$ & $\begin{array}{c}\text { Early yolk } \\
\text { deposition }\end{array}$ & $\begin{array}{c}\text { Enlarged follicles } \\
>\mathbf{8} \text { mm length }\end{array}$ & $\begin{array}{c}\text { Oviductal } \\
\text { eggs }\end{array}$ \\
\hline January & 1 & & & 100 & \\
March & 1 & & & 100 & \\
April & 5 & 40 & 20 & 40 & 50 \\
May & 6 & & & 50 & 33 \\
June & 3 & & 33 & 67 & 33 \\
July & 6 & & & 50 & \\
August & 2 & 50 & & 67 & \\
September & 3 & 33 & & 100 & \\
October & 1 & & & 100 & \\
November & 1 & & & & \\
\hline
\end{tabular}


Table 2 - Month and locality of collection, snout-vent length (SVL), clutch size and museum voucher numbers (LACM) for 23 Mastigodryas melanolomus from Costa Rica. Clutch size was estimated by counts of enlarged follicles $>8 \mathrm{~mm}$ length or oviductal eggs*.

\begin{tabular}{ccccc}
\hline Month & SVL (mm) & Clutch size & Province & LACM \# \\
\hline January & 740 & 6 & Alajuela & 153475 \\
March & 904 & $5^{*}$ & San José & 153472 \\
April & 844 & 6 & Cartagena & 153428 \\
April & 751 & 5 & Cartagena & 153439 \\
May & 686 & 5 & Puntarenas & 114114 \\
May & 690 & 6 & Cartagena & 153435 \\
May & 838 & $6^{*}$ & San José & 153437 \\
May & 665 & 6 & Cartagena & 153474 \\
May & 787 & 4 & Cartagena & 153478 \\
May & 773 & 6 & Cartagena & 153480 \\
June & 623 & 4 & Limón & 153429 \\
June & 758 & 6 & San José & 153473 \\
June & 773 & $6^{*}$ & Limón & 153483 \\
July & 658 & 5 & Guanacaste & 153420 \\
July & 770 & 2 & Cartagena & 153431 \\
July & 715 & $4^{*}$ & Puntarenas & 153457 \\
July & 735 & 6 & Cartagena & 153460 \\
July & 753 & $6^{*}$ & Guanacaste & 153465 \\
August & 751 & $5^{*}$ & Puntarenas & 153452 \\
September & 656 & 5 & Puntarenas & 153421 \\
September & 684 & 4 & Cartagena & 153433 \\
October & 707 & 3 & Cartagena & 153481 \\
November & 753 & 6 & Cartagena & 153426 \\
\hline
\end{tabular}

size and range with other $M$. melanolomus from Costa Rica. Censky and McCoy (1988) reported a mean clutch size and range of $3.1 \pm 0.90 \mathrm{SD}$, 2-5 for $42 M$. melanonomus from the Yucatan Peninsula, Mexico, which is smaller than my values reported herein.

Censky and McCoy (1988) suggested that females of $M$. melanolomus from the northern Yucatan Peninsula, Mexico, exhibited a biennial reproductive cycle (produce eggs every other year). There is insufficient data to know if this pattern occurs in M. melanonomus from Costa Rica.

Neonates of $M$. melanolomus from Yucatan, Mexico, were observed from November to
January (Censky and McCoy 1988). However, my findings combined with those of Solórzano (2004) of neonates appearing through most of the year (January to March and May to December) suggests $M$. melanolomus produces young over a longer period in Costa Rica than occurs in Mexico.

The preceding observations on the reproductive cycle of males and females indicates that M. melanolomus has a prolonged reproductive cycle in Costa Rica in which both sexes are in reproductive condition, at least, through most of the year. My data extends the period in which females with eggs and neonates occur as given in Solórzano (2004). Subsequent field 
observations are needed to correlate environmental factors (e.g. food, temperature, moisture) with the reproductive cycle as well as to ascertain the degree of geographic variation exhibited by different populations of $M$. melanolomus.

\section{Acknowledgments}

I thank Christine Thacker (LACM) for permission to examine specimens. Dustin Goto assisted with histology. Snakes are part of the CRE collection donated to LACM by Jay Savage in 1998.

\section{References}

Aldridge, R. D. 1979. Female reproductive cycles of the snakes Arizona elegans and Crotalus viridis. Herpetologica 35: 256-261.

Censky, E. J. and C. J. McCoy. 1988. Female reproductive cycles of five species of snakes (Reptilia: Colubridae) from the Yucatan Peninsula, Mexico. Biotropica 20: 326-333.
Goldberg, S. R. 2003a. Reproduction in the speckled racer, Drymobius margaritiferus (Serpentes: Colubridae), from Mexico and Central America. Texas Journal of Science 55: 195-200.

Goldberg, S. R. 2003b. Reproduction in four species of Dendrophidion from Costa Rica (Serpentes: Colubridae). Transactions of the Illinois State Academy of Science 96: 295-300.

Goldberg, S. R. 2004a. Reproduction in the coffee snake, Ninia maculata (Serpentes: Colubridae), from Costa Rica. Texas Journal of Science 56: 81-84.

Goldberg, S. R. 2004b. Notes on reproduction in the false coral snakes, Erythrolamprus bizona and Erythrolamprus mimus (Serpentes: Colubridae) from Costa Rica. Texas Journal of Science 56: 171-174.

Goldberg, S. R. 2004c. Notes on reproduction in the Central American coral snake, Micrurus nigrocinctus (Serpentes: Elapidae) from Costa Rica. Caribbean Journal of Science 40: 420-422.

Savage, J. M. 2002. The Amphibians and Reptiles of Costa Rica: A Herpetofauna Between Two Continents, Between Two Seas. The University of Chicago Press, Chicago.

Seib, R. L. 1984. Prey use in three syntopic neotropical racers. Journal of Herpetology 18: 412-420.

Solórzano, A. 2004. Snakes of Costa Rica: Distribution, Taxonomy, and Natural History. Instituto Nacional de Biodiversidad, inBio, Costa Rica.

\section{Appendix I - Specimens Examined}

COSTA RICA - Alajuela, 153462, 153475, 153509; Cartagena, 153416, 153419, 153424, 153426, 153428, 153430-153433, 153435, 153436, 153439, 153445, 153460, 153463, $153467,153474,153477,153478,153480-$ 153482, 153491, 153496, 153499, 153500, 153502, 153504, 153516; Guanacaste, 153420, 153425, 153447, 153458, 153465; Heredia,
153448, 153453, 153456, 153461; Limón, 153427, 153517,153429, 153443, 153483, 153497, 153501, 153510, 153511; Puntarenas, $114114,153418,153421,153442,153450-$ 153452, 153455, 153457, 153476, 153503, 153506, 153523; San José, 153417, 153437, 153472, 153473,153490, 153498. 